Louisiana State University

LSU Digital Commons

Faculty Publications

Department of Biological Sciences

7-1-2006

\title{
Species-habitat associations in a Sri Lankan dipterocarp forest
}

C. V.S. Gunatilleke

University of Peradeniya

I. A.U.N. Gunatilleke

University of Peradeniya

S. Esufali

University of Peradeniya

K. E. Harms

Louisiana State University

P. M.S. Ashton

Yale University

See next page for additional authors

Follow this and additional works at: https://digitalcommons.Isu.edu/biosci_pubs

\section{Recommended Citation}

Gunatilleke, C., Gunatilleke, I., Esufali, S., Harms, K., Ashton, P., Burslem, D., \& Ashton, P. (2006). Specieshabitat associations in a Sri Lankan dipterocarp forest. Journal of Tropical Ecology, 22 (4), 371-384. https://doi.org/10.1017/S0266467406003282

This Article is brought to you for free and open access by the Department of Biological Sciences at LSU Digital Commons. It has been accepted for inclusion in Faculty Publications by an authorized administrator of LSU Digital Commons. For more information, please contact ir@lsu.edu. 


\section{Authors}

C. V.S. Gunatilleke, I. A.U.N. Gunatilleke, S. Esufali, K. E. Harms, P. M.S. Ashton, D. F.R.P. Burslem, and P. S. Ashton 


\title{
Species-habitat associations in a Sri Lankan dipterocarp forest
}

\author{
C. V. S. Gunatilleke*, I. A. U. N. Gunatilleke*1, S. Esufali*, K. E. Harms†, P. M. S. Ashton‡, \\ D. F. R. P. Burslem $\S$ and P. S. Ashton\# \\ * Department of Botany, University of Peradeniya, Peradeniya 20400, Sri Lanka \\ $\dagger$ Department of Biological Sciences, Louisiana State University, Baton Rouge, LA 70808, USA and Smithsonian Tropical Research Institute, Apdo. 2072, Balboa, \\ Republic of Panama \\ $\ddagger$ School of Forestry and Environmental Studies, Yale University, New Haven, CT 06511-2189, USA \\ $\S$ School of Biological Sciences, University of Aberdeen, Cruickshank Building, St Machar Drive, Aberdeen AB24 3UU, Scotland, UK \\ \# Arnold Arboretum, Harvard University, 22 Divinity Avenue, Cambridge, MA 02138, USA \\ (Accepted November 2005)
}

\begin{abstract}
Forest structure and species distribution patterns were examined among eight topographically defined habitats for the 205 species with stems $\geq 1 \mathrm{~cm}$ dbh inhabiting a 25-ha plot in the Sinharaja rain forest, Sri Lanka. The habitats were steep spurs, less-steep spurs, steep gullies and less-steep gullies, all at either lower or upper elevations. Mean stem density was significantly greater on the upper spurs than in the lower, less-steep gullies. Stem density was also higher on spurs than in gullies within each elevation category and in each upper-elevation habitat than in its corresponding lower-elevation habitat. Basal area varied less among habitats, but followed similar trends to stem density. Species richness and Fisher's alpha were lower in the upper-elevation habitats than in the lower-elevation habitats. These differences appeared to be related to the abundances of the dominant species. Of the 125 species subjected to torus-translation tests, 99 species (abundant and less abundant and those in different strata) showed at least one positive or negative association to one or more of the habitats. Species associations were relatively more frequent with the lower-elevation gullies. These and the previous findings on seedling ecophysiology, morphology and anatomy of some of the habitat specialists suggest that edaphic and hydrological variation related to topography, accompanied by canopy disturbances of varying intensity, type and extent along the catenal landscape, plays a major role in habitat partitioning in this forest.
\end{abstract}

Key Words: Environmental heterogeneity, habitat specialization, rain forest, Sinharaja Forest Dynamics Plot, specieshabitat associations, Sri Lanka, torus translations

\section{INTRODUCTION}

Both niche partitioning and dispersal-assembly processes have been invoked to explain species co-existence and controls on plant distribution in species-rich tropical tree communities (Hubbell 2001, Potts et al. 2004, Whitfield 2002, Wright 2002). A role for niche partitioning is suggested by associations between plant distributions and environmental conditions at a variety of spatial scales in both the New and Old World Tropics (Baillie et al. 1987, Debski et al. 2002, Fine et al. 2005, Gartlan et al. 1986, Gimaret-Carpentier et al. 1998, 2003; Harms et al. 2001, Itoh et al. 2003, Phillips et al. 2003, Potts et al. 2002). The dispersal-assembly perspective proposes that

\footnotetext{
${ }^{1}$ Corresponding author: I. A. U. N. Gunatilleke, Department of Botany, Faculty of Science, University of Peradeniya, Peradeniya 20400, Sri Lanka.Email: savnim@slt.lk, savnimg@yahoo.com
}

communities are non-equilibrium assemblages of species brought together by accidents of dispersal, and that localized niche partitioning plays a limited role in species coexistence. The importance of seed-dispersal limitation for determining the distribution of species at small scales has been demonstrated in recent research in tropical forests (Dalling et al. 2002, Hubbell et al. 1999, Webb \& Peart 2001). However, the relative importance of the two sets of mechanisms in controlling structure of tropical rain-forest communities that are rich in closely related species is poorly understood. This results in part because, in most cases, the potentially subtle differences in lifehistory characteristics among species with contrasting habitat associations have not been examined.

Central to understanding the distribution patterns of plant species is the identification of habitats at scales that are relevant to plant populations. The limitations of small plots in differentiating local habitats have led to 
the establishment of large plots (16-52 ha) in tropical forests where all individuals $\geq 1 \mathrm{~cm}$ diameter at breast height (dbh) have been mapped, measured and identified to species (Condit 1995, Condit et al. 1996, Harms et al. 2001, Losos \& Leigh 2004, Manokaran et al. 1992, Sukumar et al. 1992, Valencia et al. 2004). Such data sets now provide opportunities to test species-habitat relationships as one step towards understanding the factors that determine species-distribution patterns.

The 25-ha Forest Dynamics Plot (FDP) at Sinharaja, south-west Sri Lanka, is among the most topographically heterogeneous FDPs co-ordinated within the network of the Center for Tropical Forest Science (CTFS), and has the highest elevational range $(151 \mathrm{~m})$ of the CTFS plots (comparative data for the various CTFS plots are available on the CTFS website: http://www.ctfs.si.edu). While supporting a very large number of stems per unit area relative to the other large plots, the Sinharaja FDP also has several series of closely related congeneric, sympatric species (Ashton et al. 2004, Gunatilleke et al. 2004). The majority of these are endemic to Sri Lanka. Understanding the presence or absence of habitat preferences, especially among these congeneric species could shed some light on the means by which they coexist.

Species-habitat associations have now been described for FDPs in a semi-deciduous forest on Barro Colorado Island in Panama (Harms et al. 2001), lowland evergreen forests at Yasuni in Ecuador (Valencia et al. 2004) and Lambir in Sarawak (Davies et al. 2005). At Sinharaja, unlike the other three sites, our interpretation of differences in species distribution was facilitated by a substantial body of experimental research that has investigated the mechanistic basis of species-habitat associations among closely-related and sympatric species within the important tree genera Shorea, Mesua and Syzygium (Ashton 1995, Ashton \& Berlyn 1992, Ashton et al. 1995, 2001, 2006, Burslem et al. 2001, Gamage et al. 2003, Gunatilleke et al. 1997, Singhakumara et al. 2003). The combination of habitat associations plus species traits and performance characteristics provides a powerful opportunity to address the challenge of determining the extent to which differences in species responses to resource availability contribute to their coexistence in species-rich tropical forests (Hubbell 2001).

The Sinharaja FDP was divided into eight habitats based on elevation, convexity and slope to address the following questions: (1) Do stem density, basal area, species richness and representation by different growth forms vary among habitats? (2) What proportion of species is significantly associated with one or more of these habitats? (3) Are more species associated with some habitats than with others? (4) Are more-abundant species differentially associated with habitats compared with less-abundant species? (5) Do species of different growth forms, i.e. structural guilds, differentially associate with these habitats? (6) Are significant associations, especially differences among congeneric species, consistent with the available experimental evidence for their ecophysiological differences?

\section{METHODS}

\section{Study area}

The area studied is the Sinharaja Forest Dynamics Plot (FDP), a $500 \times 500$-m (25-ha) permanent study plot (Figure 1). The Sinharaja FDP is located in the lowland rain forest of the Sinharaja UNESCO World Heritage Site at the centre of the ever-wet south-western region of Sri Lanka $\left(6^{\circ} 21-26^{\prime} \mathrm{N}, 80^{\circ} 21-34^{\prime} \mathrm{E}\right)$. The forest has been classified as a Mesua-Doona community (de Rosayro 1942), and on a regional scale it represents a mixed dipterocarp forest (Ashton 1964, Whitmore 1984).

Topographically, the Sinharaja FDP spans the elevational range of $424 \mathrm{~m}$ to $575 \mathrm{~m}$ asl. The Sinharaja FDP includes a valley lying between two slopes, a steeper higher slope facing south-west and a less-steep slope facing north-east (Figure 1). Seepage ways, spurs, small hillocks, at least two perennial streams and several seasonal streamlets cut across these slopes. The floristics and forest structure within the plot as a whole have been documented in Gunatilleke et al. (2004). The Sinharaja FDP is representative of the 'ridge-steep slopevalley' landscape of the lowland through mid-elevational rain forests of south-western Sri Lanka. This landform is a result of differential weathering and erosion of lithologically less-resistant Precambrian metamorphic bedrock along structurally controlled parallel strike ridges and valleys (Cooray 1984, Erb 1984).

\section{Vegetation sampling}

To establish the Sinharaja FDP, we followed the methodology established by Hubbell \& Foster (1983) and Manokaran et al. (1992), to maintain census uniformity with similar plots within the CTFS network. The Sinharaja FDP was established in 1993, when it was demarcated on the horizontal plane into 625 quadrats of $20 \times 20 \mathrm{~m}$ $\left(400 \mathrm{~m}^{2}\right)$ each. The trees in the plot were censused over the period 1994-1996, when the diameters of all freestanding stems $\geq 1 \mathrm{~cm}$ dbh were measured. Each stem was mapped and identified to species, using the National Herbarium of Sri Lanka, and Dassanayake \& Fosberg (1980-2000).

\section{Topographic parameters and habitat categorization}

Habitats of the Sinharaja FDP were identified by three physical parameters, viz. elevation, slope and convexity, in each of the $20 \times 20-\mathrm{m}$ quadrats. The mean of the 


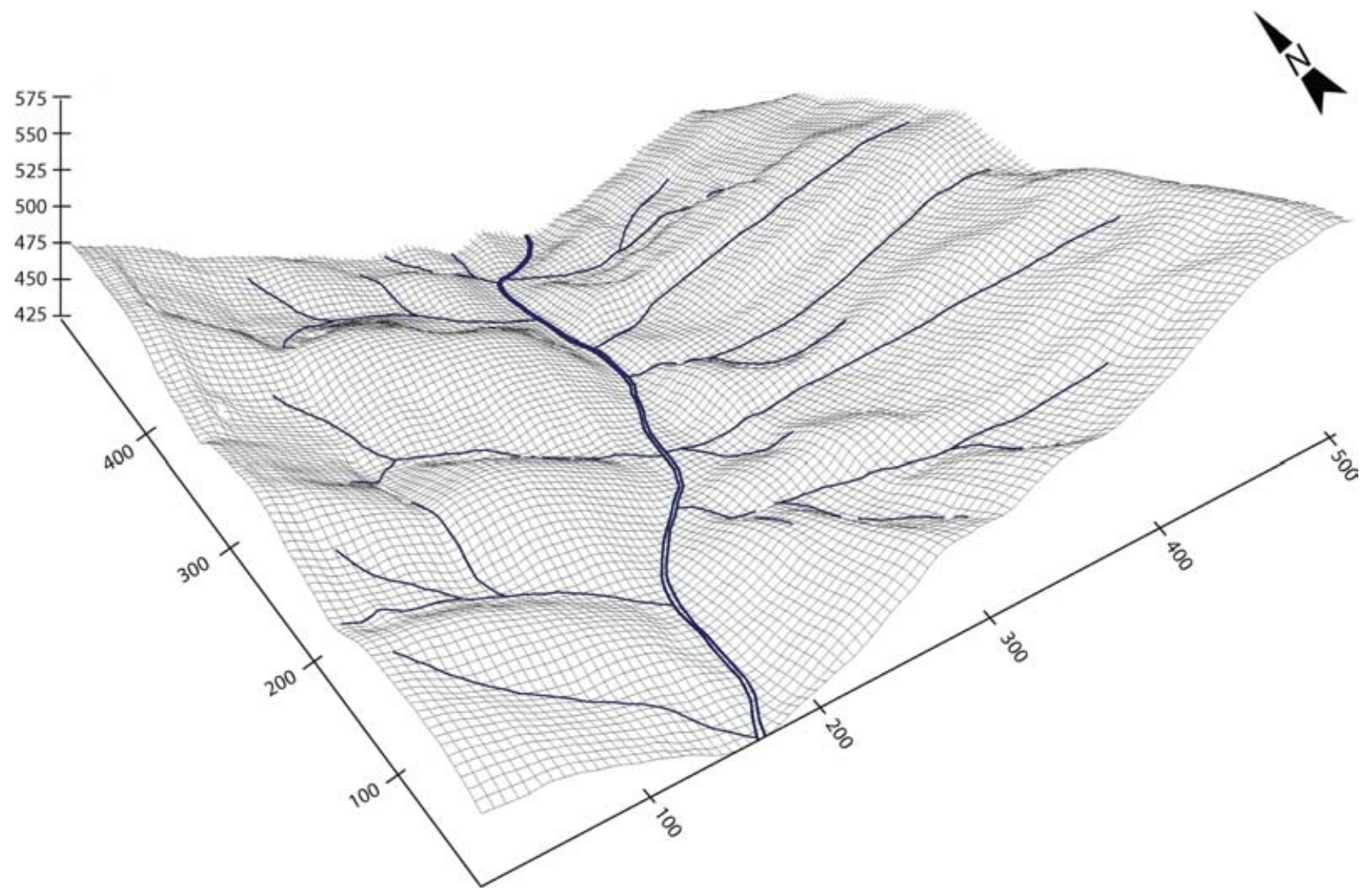

Figure 1. Topography of the 25-ha forest dynamics plot (all scales in metres) in Sinharaja, Sri Lanka.

elevations at the four corners of each quadrat gave the quadrat's elevation. Each quadrat was divided into four triangular planes, each formed by joining three corners of the quadrat. The average angular deviation of these planes from horizontal provided the slope (Harms et al. 2001). Convexity was calculated as in Yamakura et al. (1995), i.e. as a quadrat's mean elevation relative to the mean elevations of its eight immediate neighbouring quadrats (the focal quadrat mean elevation minus the mean elevation of the neighbouring quadrats). For each of the perimeter quadrats of the plot, for which the number of neighbouring quadrats was $<8$, convexity was calculated as the elevation of the centre point of the focal quadrat minus the mean elevation of its four corners. Positive values indicate convex surfaces, whereas negative values indicate concave surfaces.

Bivariate scatterplots for each pair of topographic variables confirmed that they were independent of each other, with $\mathrm{r}^{2}$ values ranging between 0.0356 and 0.141 . These three variables represent mutually orthogonal topographic properties, so we used all three to define eight topographic habitats. Each $20 \times 20$-m quadrat was assigned to one of two categories of elevation (upper vs. lower, divided by the median elevation value for the FDP), slope (steep vs. less-steep divided by the median slope value), and convexity (Table 1 , Figure 2a).The abbreviations of the habitat categories used in the entire paper are explained in Table 1.

Table 1. The physical parameters used to define habitat categories of each $20 \times 20$-m quadrat of the Sinharaja Forest Dynamics Plot.

\begin{tabular}{|c|c|c|c|c|c|}
\hline Habitat category & Elevation $(\mathrm{m})$ & Slope $\left(^{\circ}\right)$ & Convexity & Number (and \%) of quadrats & Total area on plot (ha) \\
\hline Upper-elevation steep spurs (USS) & $>460$ & $>25$ & $>0$ & $104(17)$ & 4.2 \\
\hline Upper-elevation steep gullies (USG) & $>460$ & $>25$ & $\leq 0$ & $68(11)$ & 2.7 \\
\hline Upper-elevation less-steep spurs (ULS) & $>460$ & $\leq 25$ & $>0$ & $108(17)$ & 4.3 \\
\hline Upper-elevation less-steep gullies (ULG) & $>460$ & $\leq 25$ & $\leq 0$ & $32(05)$ & 1.3 \\
\hline Low-elevation steep spurs (LSS) & $<460$ & $>25$ & $>0$ & $52(08)$ & 2.1 \\
\hline Low-elevation steep gullies (LSG) & $<460$ & $>25$ & $\leq 0$ & $59(09)$ & 2.4 \\
\hline Low-elevation less-steep spurs (LLS) & $<460$ & $\leq 25$ & $>0$ & $48(08)$ & 1.9 \\
\hline Low-elevation less-steep gullies (LLG) & $<460$ & $\leq 25$ & $\leq 0$ & $155(25)$ & 6.2 \\
\hline
\end{tabular}




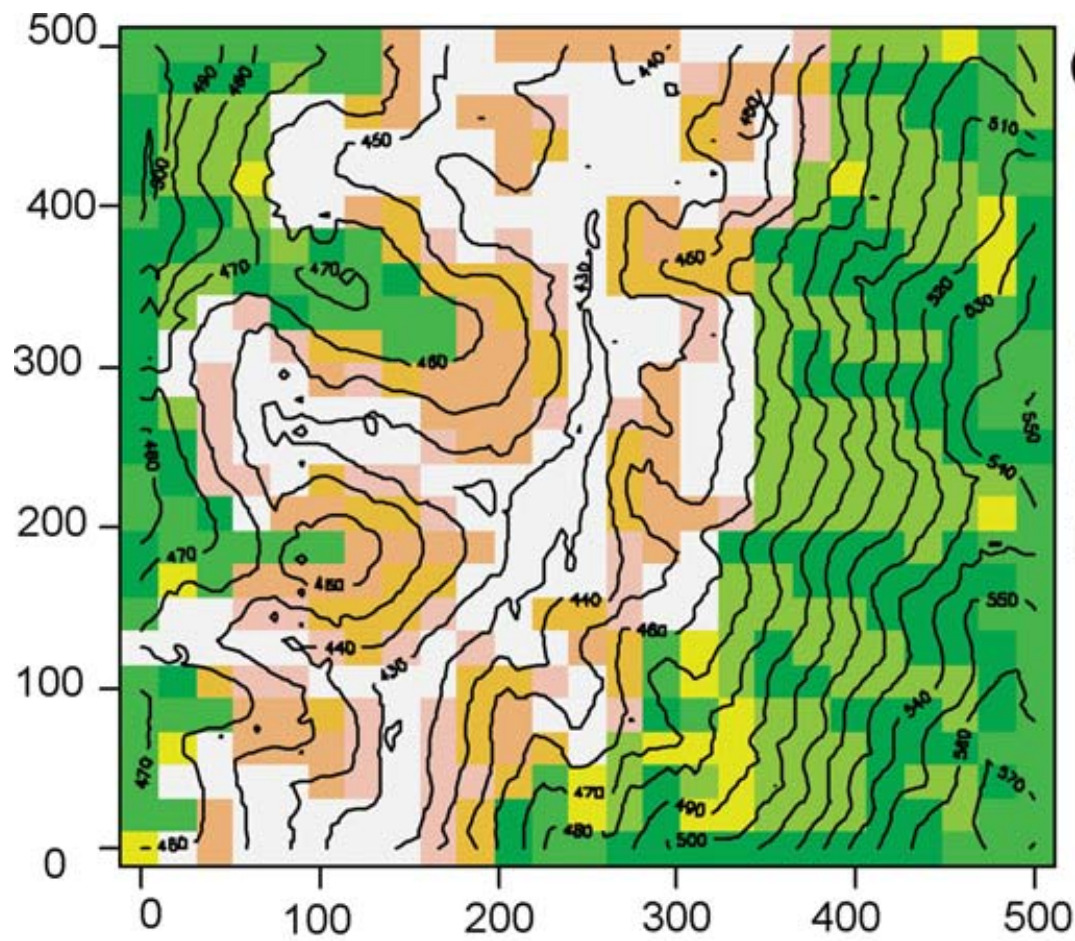

(a)

\section{Habitats Based on Elevation, Slope \& Convexity}

$\square$ Upper Steep Spurs

$\square$ Upper Less-Steep Spurs

$\square$ Upper Steep Gullies

Upper Less-Steep Gullies

\section{Low Steep Spurs}

Low Less-Steep Spurs

Low Steep Gullies

Low Less-Steep Gullies (b)

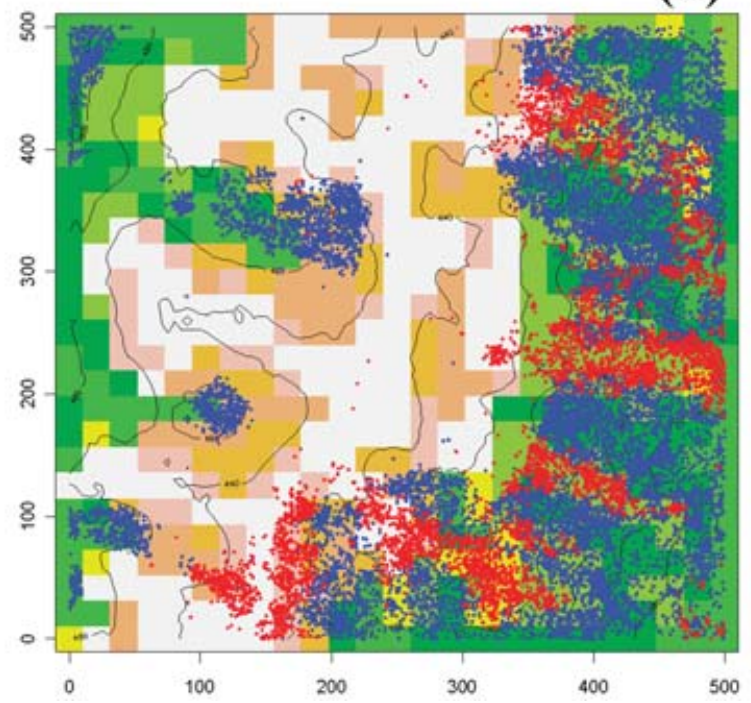

(c)

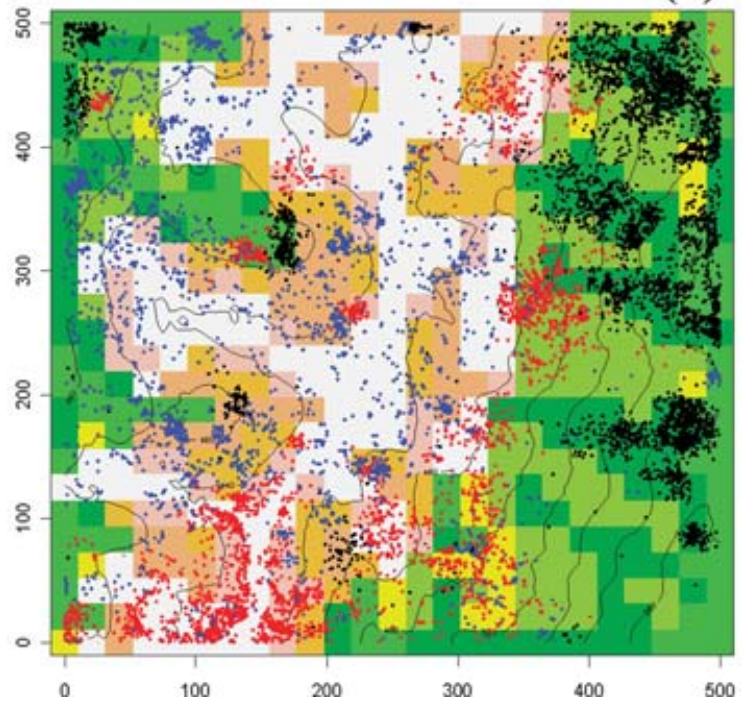

Figure 2. Habitats and selected species distribution patterns within the 25-ha forest dynamics plot in Sinharaja, Sri Lanka. (a) Habitats based on elevation, slope and convexity, each at two levels. Distribution patterns of (b) Mesua nagassarium (blue) found predominantly on upper-elevation steep spurs and Mesua ferrea (red) found predominantly on upper steep and less-steep gullies. Distribution patterns of (c) Shorea worthingtonii (black) found predominantly on upper steep spurs, Shorea trapezifolia (blue) found predominantly on the low-elevation less-steep spurs, and Shorea megistophylla (red) found predominantly on the low-elevation less-steep gullies.

\section{Structural and floristic characteristics among habitats}

To assess the structural characteristics of the vegetation in the different habitats, the means of density and basal area per quadrat in each habitat were compared.
Similarly, species richness and Fisher's alpha diversity per quadrat were calculated and compared among habitats. Significant differences in species richness and Fisher's alpha diversity among habitats were determined using torus-translation tests, described below. 
Table 2. Mean and standard error for structural (density and basal area) and floristic (species richness and Fisher's alpha diversity) characteristics per quadrat among habitats in the Sinharaja 25-ha Forest Dynamics Plot. Total number of free-standing species identified in the plot was 205. Significance among the respective values column-wise was tested using two-tailed torus-translation tests, $\mathrm{P}<0.025$ for either tail. An asterisk $\left({ }^{*}\right)$ indicates a significant departure from the null expectation. Abbreviations of habitat categories are explained in Table 1.

\begin{tabular}{lccccc}
\hline Habitat categories & Area (ha) & Mean no. of individuals & Mean basal area $\left(\mathrm{m}^{2}\right)$ & Mean no. of species & Mean Fisher's alpha \\
\hline Upper-elevation habitats & & & & & \\
$\quad$ USS & 4.2 & $409 \pm 11^{*}$ & $2.36 \pm 0.08$ & $46.7 \pm 0.8$ & $14.6 \pm 0.4^{*}$ \\
ULS & 2.7 & $402 \pm 13^{*}$ & $2.26 \pm 0.10$ & $47.9 \pm 1.2$ & $15.1 \pm 0.6$ \\
USG & 4.3 & $322 \pm 10$ & $1.90 \pm 0.07$ & $47.0 \pm 0.7$ & $15.5 \pm 0.4$ \\
ULG & 1.3 & $357 \pm 18$ & $1.81 \pm 0.11$ & $51.7 \pm 1.9$ & $17.2 \pm 0.8$ \\
Low-elevation habitats & & & & & \\
LSS & 2.1 & $368 \pm 14$ & $2.05 \pm 0.09$ & $56.9 \pm 1.7$ & $20.4 \pm 0.9$ \\
LLS & 2.4 & $352 \pm 18$ & $1.88 \pm 0.09$ & $54.0 \pm 1.5$ & $19.7 \pm 0.8$ \\
LSG & 1.9 & $322 \pm 17$ & $1.51 \pm 0.07$ & $53.4 \pm 1.3$ & $19.4 \pm 0.8$ \\
LLG & 6.2 & $220 \pm 6^{*}$ & $1.22 \pm 0.04$ & $49.6 \pm 0.8$ & $21.1 \pm 0.4^{*}$ \\
\hline
\end{tabular}

\section{Significant associations of species with habitats}

Positive and negative associations of species with habitats were determined by torus-translation tests (Harms et al. 2001). The tests assess the similarity between the spatial structure of each focal species population and each habitat. For each species, the observed relative densities of stems in each of the habitats were compared with expected relative densities. To obtain the expected values, the true habitat map was shifted about a two-dimensional torus by $20-\mathrm{m}$ increments to exhaustively produce all possible $20-\mathrm{m}$ translations of the true habitat map in the four cardinal directions. Each of the 625 maps provided an estimate of the expected relative density.

A species was significantly positively associated with a particular habitat if its relative density in the true habitat map was $>97.5 \%$ of the values obtained from translated maps. A significant negative association occurred if the relative density in the true map was $<97.5 \%$ of the values from translated maps. In the Sinharaja FDP, 205 tree species with stems $\geq 1 \mathrm{~cm}$ dbh and 10 species of liana have been identified. For the torus-translation tests, we used the 125 tree species with a density $\geq 100$ individuals in the 25-ha plot.

We also used torus-translations to test whether species richness, Fisher's alpha diversity, stem density and basal area differed among habitats. In each case, the observed value for a given habitat was compared with a frequency distribution of expected values generated by an exhaustive set of 20-m incremental torus-translations (analogous to the procedure used to assess species associations).

\section{RESULTS}

\section{Spatial distribution of habitats}

The most extensive habitat was the LLG (6.2 ha), whereas the least extensive and most fragmented was the ULG (1.3 ha; Table 1, Figure 2a). The remaining habitats ranged from 1.9 to 4.3 ha in extent. USS and ULS were greater in extent (4.2-4.3 ha) than the USG and ULG (1.3$2.7 \mathrm{ha}$ ). The extent of the LLG was similar to that of the three remaining low-elevation habitats combined.

\section{Structural and floristic differences among habitats}

The LLG had the lowest density of individuals $\geq 1 \mathrm{~cm}$ $\mathrm{dbh}$, whereas the USS and ULS had the highest densities ( $>400$ individuals per quadrat, Table 2); in these cases the densities depart significantly from expectations. The densities of the remaining habitats had values between these extremes. Spurs at both elevations, irrespective of whether they were steep or less steep, had significantly higher densities compared with gullies at the same elevation.

Mean basal area among habitats ranged from $1.22 \mathrm{~m}^{2}$ in the LLG to $2.36 \mathrm{~m}^{2}$ in the USS, although no mean value differed significantly from expectations (Table 2). The basal area of the tree community on spurs was higher than that in gullies at each of the two elevations, as with stem density. The value for each upper-elevation habitat was greater than that of the corresponding habitat at lower elevation.

Species richness per quadrat showed little variation among habitats and ranged from 46.7 in the USS to a high of 56.9 in the LSS (Table 2). Species diversity per quadrat (measured using Fisher's alpha) among the habitats ranged from 14.6 to 21.1 (Table 2). In the upperelevation habitats, where the diversity was at the lower end of the range, spurs showed lower values than gullies. The diversity values of the low-elevation habitats were more or less similar, but among them the LLG had the highest diversity. Diversity was significantly higher in LLG than in USS. The differences among all other values were not statistically significant.

\section{Species-habitat associations using torus-translation tests}

Based on torus-translation tests, a total of 175 significant associations (94 positive and 81 negative) were observed 
Table 3. Numbers of positive and negative associations observed among the different habitats defined by topographic parameters in the Sinharaja Forest Dynamics Plot, based on two-tailed torus-translation tests, $\mathrm{P}<0.025$ for either tail. Abbreviations of habitat categories are explained in Table 1.

\begin{tabular}{|c|c|c|c|}
\hline Habitat category & Total no. of significant associations & $\begin{array}{c}\text { No. of positive associations } \\
\text { in each habitat }\end{array}$ & $\begin{array}{c}\text { No. of negative associations } \\
\text { in each habitat }\end{array}$ \\
\hline \multicolumn{4}{|l|}{ Upper-elevation habitats } \\
\hline USS & 24 & 3 & 21 \\
\hline ULS & 25 & 7 & 18 \\
\hline USG & 12 & 5 & 7 \\
\hline ULG & 5 & 3 & 2 \\
\hline Totals in upper-elevation habitats & 66 & 18 & 48 \\
\hline \multicolumn{4}{|l|}{ Low-elevation habitats } \\
\hline LSS & 6 & 5 & 1 \\
\hline LLS & 13 & 11 & 2 \\
\hline LSG & 24 & 13 & 11 \\
\hline LLG & 66 & 47 & 19 \\
\hline Totals in low-elevation habitats & 109 & 76 & 33 \\
\hline $\begin{array}{l}\text { Total nos. and (\%) of significant } \\
\text { associations in all categories }\end{array}$ & 175 & $94(54 \%)$ & $81(46 \%)$ \\
\hline
\end{tabular}

(Table 3). LLG produced the highest number of significant associations. There were 66 significant associations among the four upper-elevation habitats, of which 18 were positive and 48 were negative. The corresponding values in the four low-elevation habitats totalled 109 , with 76 positive and 33 negative (Table 3). In the upper-elevation habitats, spurs had more significant associations (mostly negative) than gullies, but in the lowerelevation habitats the pattern was reversed and the gullies had more associations (mostly positive) than spurs.

\section{Species associated with habitats}

Of the 125 species with densities $\geq 100$ individuals on the plot, 99 species $(79 \%)$ were positively or negatively associated with one or more of the different habitats, i.e. they were disproportionately over- or under-represented in some habitats (Appendix 1). The remaining 26 species were not significantly associated with any of the eight habitats and were distributed as expected by chance with respect to these habitats. The five most abundant among these species were Myristica dactyloides, Diospyros acuminata, Mangifera zeylanica, Shorea stipularis and Chaetocarpus coriaceus with 2694, 1569, 1231, 984 and 861 individuals on the 25-ha plot, respectively. The remaining 19 species each had abundances ranging from 106 to 706 individuals in the plot.

Among the 99 species significantly associated with habitats, 16 were positively associated with one or more of the upper-elevation habitats and 12 of these 16 were also negatively associated with either one or both lower-elevation gullies (Appendix 1). The number of species that was positively associated with the lowerelevation habitats was $65 ; 28$ of them were also negatively associated with one or two of the upper- elevation habitats (Appendix 1). Species that were positively associated with one habitat type and negatively associated with a contrasting habitat are exemplified by the USS-associated species Mesua nagassarium, Shorea worthingtonii, Agrostistachys intramarginalis and the ULS-associated species Humboldtia laurifolia and Memecylon arnottianum. Examples of species significantly positively associated with a lower-elevation habitat and significantly negatively associated with the upperelevation steep slope habitat include Bhesa ceylanica, Palaquium canaliculatum and Urophyllum ellipticum. Among the 18 species that showed only negative associations, 11 including Shorea disticha, Shorea affinis and Shorea congestiflora were biased against the lowerelevation habitats and seven, including Anisophyllea cinnamomoides and Cullenia ceylanica, were biased against the upper-elevation habitats (Appendix 1).

\section{Distribution patterns of abundant and less-abundant species}

Species with $>800$ individuals representing the quartile of most abundant species within the Sinharaja FDP were considered abundant; less-abundant species had 100800 individuals (Table 4; Appendix 1). The percentage of species positively and negatively associated with habitats hardly differed between abundant and less-abundant species (Table 4). Among the 33 positively associated abundant species, 10 (including Mesua nagassarium, Palaquium petiolare, Hydnocarpus octandra) were positively associated with one or two of the upper-elevation habitats, while the other 23 (including Palaquium canaliculatum and Urophyllum ellipticum) were positively associated with one or two of the lower-elevation habitats (Table 4, Appendix 1). Among the 48 positively associated lessabundant species, the corresponding values were 6 and 
Table 4. Proportions of positively and negatively associated abundant (> 800 individuals) and less abundant (100-800 individuals) species among habitats, defined by topographic parameters in the Sinharaja Forest Dynamics Plot, based on two-tailed torus-translation tests, $\mathrm{P}<0.025$ for either tail. The number of significantly associated species in each abundance class is indicated within parentheses and these were used to calculate the percentages shown in the last row (for details refer to Appendix 1). Abbreviations of habitat categories are explained in Table 1.

\begin{tabular}{|c|c|c|c|c|}
\hline \multirow[b]{2}{*}{ Habitat category } & \multicolumn{2}{|c|}{$\begin{array}{c}\text { No. of species positively associated } \\
\text { with each habitat }\end{array}$} & \multicolumn{2}{|c|}{$\begin{array}{c}\text { No. of species negatively associated } \\
\text { with each habitat }\end{array}$} \\
\hline & $\begin{array}{l}\text { Abundant spp. } \\
\text { (41) }\end{array}$ & Less-abundant spp. (58) & $\begin{array}{l}\text { Abundant spp. } \\
\text { (41) }\end{array}$ & $\begin{array}{l}\text { Less-abundant spp. } \\
\text { (58) }\end{array}$ \\
\hline \multicolumn{5}{|l|}{ Upper-elevation habitats } \\
\hline USS & 3 & 0 & 6 & 15 \\
\hline ULS & 2 & 5 & 6 & 12 \\
\hline USG & 4 & 1 & 0 & 7 \\
\hline ULG & 3 & 0 & 0 & 2 \\
\hline Subtotals & 10 & 6 & 10 & 26 \\
\hline \multicolumn{5}{|l|}{ Low-elevation habitats } \\
\hline LSS & 3 & 2 & 0 & 1 \\
\hline LLS & 4 & 7 & 1 & 1 \\
\hline LSG & 5 & 8 & 5 & 6 \\
\hline LLG & 18 & 29 & 13 & 6 \\
\hline Subtotals & 23 & 42 & 13 & 10 \\
\hline $\begin{array}{l}\text { Total no. and (\%) of significantly } \\
\text { associated species in each category }\end{array}$ & $33(80 \%)$ & $48(83 \%)$ & $23(56 \%)$ & $36(62 \%)$ \\
\hline
\end{tabular}

42, respectively. Some species in these habitats were also negatively associated with one of the remaining habitats, indicating that they were significantly underrepresented in them. A total of 18 species, eight abundant and 10 lessabundant, were only negatively associated with certain habitats; they failed to show any positive associations. Among these negatively associated species, seven were biased against upper-elevation habitats and eleven were biased against lower-elevation habitats (Appendix 1).

Twenty-four species out of the total of 99 were positively associated with spurs (Appendix 1). Among them, 10 species (five abundant and five less-abundant species) were positively associated with upper-elevation spurs and 14 were positively associated with lower-elevation spurs (five abundant and nine less-abundant species). Only five abundant and one less-abundant species were positively associated with the upper-elevation gullies. In contrast, 19 abundant and 33 less-abundant species were positively associated with the lower-elevation gullies (Appendix 1).

\section{Habitat associations of species in different life-forms}

The 125 species tested represented 19 canopy, 34 subcanopy, 30 understorey tree and 42 treelet and shrub species (Table 5; Appendix 1). Among the canopy, subcanopy and treelet and shrub species tested, 84-86\% were significantly associated with the different habitats in the 25-ha plot; among the understorey tree species, $60 \%$ were significantly associated. The proportions of significant species with respect to both the abundant and less-abundant species in these growth forms also followed a similar trend.
Table 5. Proportions of significantly associated species in each growth form among the abundant ( $>800$ individuals) and less abundant (100800 individuals) species, based on two-tailed torus-translation tests, $\mathrm{P}<0.025$ for either tail.

\begin{tabular}{lrcc}
\hline $\begin{array}{l}\text { Abundance/growth } \\
\text { categories }\end{array}$ & No. tested & $\begin{array}{c}\text { Number } \\
\text { significant }\end{array}$ & $\begin{array}{c}\text { \% significant in } \\
\text { each growth form }\end{array}$ \\
\hline Abundant species & 13 & 11 & 85 \\
$\quad$ Canopy species & 14 & 12 & 86 \\
$\quad$ Subcanopy species & 8 & 5 & 63 \\
$\quad$ Understorey tree & & & \\
$\quad$ species & 13 & 13 & 100 \\
$\quad$ Shrub/treelet species & 48 & 41 & 85 \\
All growth forms & & & \\
Less-abundant species & 6 & 5 & 83 \\
$\quad$ Canopy species & 20 & 17 & 85 \\
$\quad$ Subcanopy species & 22 & 13 & 59 \\
$\quad$ Understorey tree & & & 79 \\
$\quad$ species & 29 & 23 & 75 \\
$\quad$ Shrub/treelet species & 77 & 58 & 84 \\
All growth forms & & & 85 \\
All species & 19 & 16 & 60 \\
$\quad$ Canopy species & 34 & 29 & 79 \\
$\quad$ Subcanopy species & 30 & 18 & \\
$\quad$ Understorey tree & & & \\
$\quad$ species & 42 & 36 & \\
$\quad$ Shrub/treelet species & 125 & 99 & \\
All growth forms & & & \\
\hline
\end{tabular}

\section{DISCUSSION}

\section{Forest structure and habitat associations at Sinharaja}

The structural and floristic characteristics of the Sinharaja FDP appear to reflect the different micro-environmental conditions prevailing within its elevational range of 
$151 \mathrm{~m}$. For the three most abundant species (a canopy tree, Mesua nagassarium, a treelet, Agrostistachys intramarginalis, and an understorey tree, Humboldtia laurifolia) in the upper-elevation spurs, their exceptionally high densities (14 880, 18022 and 22459 individuals in $25 \mathrm{ha}$ ) indicate their differential success in that habitat. Soils are shallower there and more prone to desiccation. These sites may experience lower availability of irradiance at ground level, moisture and nutrients (Ashton 1995, Ashton \& Berlyn 1992, Ashton et al. 1995, Burslem et al. 2001). Data from aerial photographic interpretations (unpublished) revealed that canopy crown densities increase and canopy crown size and canopy porosity decrease from valley to ridge, presumably driven by the hydrology of the site. These observations also suggest that the forest canopy is more compact and uniform on the ridges than in the valley. An experimental study with seedlings of Mesua nagassarium that were grown in artificial shelters for $2 \mathrm{y}$ demonstrated their ability to endure deep shade and low soil water availability (Ashton et al. 2006).

In the lower-elevation habitats, on the other hand, soils are wetter and light measurements have shown higher mean and variance of irradiance (Ashton \& Berlyn 1992). In valleys, larger canopy gaps are found than on ridges because there is a stronger tendency for trees to die in groups (I. A. U. N. Gunatilleke et al. pers. obs.). Larger and more frequent openings in the moist valley sites, especially along streams of the lower elevations, support a greater cover of herbaceous species of Strobilanthes, Coleus and Ochlandra (not tallied in the 25-ha plot) sometimes at the expense of woody plants (similar to a pattern observed by Harms et al. 2004 for four Neotropical sites). In time, these gaps in different stages of closure provide greater light heterogeneity than those in upper slopes. These lowerelevation gaps support a larger suite of species, adapted to different light intensities, each with lower abundances. The three most abundant species in the lower-elevation habitats are all treelet/shrub species (Psychotria nigra, Urophyllum ellipticum and Schumacheria castaneifolia) each of whose population densities are much lower (6087, 4102 and 3550 individuals, respectively, in 25 ha) than those of the most abundant species in the upper-elevation habitats. Similar patterns of forest structure with lower mean tree density and basal area in valleys compared to mid-slope and upper-ridge sites have been observed in the topographically heterogeneous FDP at Yasuni, Ecuador (Valencia et al. 2004) and in Brunei (Ashton 1964).

In the south-western Sri Lankan landscape, forest trees on ridge tops and rocky upper slopes are susceptible to water shortage, particularly during El Niño years, and also to lightning strikes (Ashton et al. 2001). The gaps created by these events are often small as the trees die standing and create only small canopy disturbances. Consequently, these habitats also appear to have relatively lower rates of soil disturbance by tip-up mound formation during tree-fall. Furthermore, on these thin soils interspersed with rocky outcrops, the availability of nutrients for tree growth is also limited. These conditions may lead to habitat specialization and canopy dominance by shadetolerant and slow-growing species that are adapted to regenerate preferentially in smaller gaps (e.g. Shorea worthingtonii) and to lower species richness. Mid-slopes on the other hand, are prone to small-scale earth slips and landslides, and the lower slopes with a higher water table have trees with shallow rooting systems. Both of these processes result in multiple tree falls. Windthrows from sudden downdrafts are also channelled into valleys, and cause relatively greater disturbance both above- and below-ground (Ashton et al. 2001). Fastgrowing species with a high shoot:root ratio (e.g. Shorea megistophylla) establish more successfully in these lowerelevation habitats than in upper slopes and ridge tops, and exhibit both habitat specialization and canopy dominance (Ashton et al. 1995). The relatively larger gaps with greater soil disturbance, higher soil nutrient availability, and larger and more frequent canopy openings at lower elevations may result in higher species diversity, and select for abundant species that are mostly shadeintolerant. As a result of the relatively greater extent of canopy and soil disturbance on mid-slopes and valleys, greater opportunities are made available for resource partitioning among species present in the seedling bank. Thus, in the Sinharaja landscape, while topographic and edaphic habitat partitioning appear to play a significant role in the spatial distribution of species, intermediate disturbance conditions may contribute to higher species diversity at lower elevations than in the more stable conditions prevailing at upper elevations (cf. Connell 1978). A greater tree species diversity in low-elevation valley plots than nearby ridge-top plots has also been observed in lowland dipterocarp forests in Sumatra (Rennolls \& Laumonier 2000) and Sabah (Nilus 2003). The mechanisms that determine these consistent patterns of tree diversity across topographic gradients have not been fully explored.

\section{Comparisons with other forest dynamics plots}

This study shows that nearly four-fifths (79\%) of species examined are associated with topographically defined habitats in the Sinharaja FDP. Among the plots examined using comparable methods, Sinharaja stands among those with the highest percentage of species demonstrating significant habitat associations: the plot on Barro Colorado Island, Panama, has 33\% of its species significantly associated with habitats, those at Mudumalai in India and Korup in Cameroon have $68 \%$ each (Anon. 2003, Harms et al. 2001), but 
that at Lambir in Sarawak - also a topographically heterogeneous plot - has $86.8 \%$ of species significantly biased with respect to the habitat gradient of the plot (Davies et al. 2005). This study may have underestimated the total percentage of habitat specialists at Sinharaja, however, by arbitrarily confining the analysis only to an elevational and topographic gradient. There are, for instance, aspect-related patterns of species distribution within the plot: for example, Shorea trapezifolia and Syzygium rubicundum are concentrated on the northeast facing slope, while Shorea megistophylla, S. disticha, $S$. cordifolia and $S$. worthingtonii are concentrated on the south-west facing slope. These two associations are widespread in the Sinharaja landscape and appear to be correlated with soil depth and possibly occasional largescale canopy openings (Ashton et al. 2001, Gamage et al. 2003). Using an index of relative neighbourhood density (a probability density function), Condit et al. (2000) observed that in both the Sinharaja and Lambir FDPs, the species distribution patterns followed topographic features resulting in habitat-related patchiness more than in the two more topographically homogeneous Forest Dynamics Plots at BCI and Pasoh. The eight habitat classification appears to have successfully represented much of the topographic variability of the Sinharaja FDP.

\section{Mechanistic basis of habitat specialization}

The strong relationships between species distributions and habitats are consistent with ecophysiological, morphological and anatomical studies carried out with seedlings of Shorea, Mesua, Dipterocarpus and Syzygium species in natural canopy gaps along topographic catenas and in artificial shelters, each over a period of $2 \mathrm{y}$ (Ashton 1995, Ashton \& Berlyn 1992, Ashton et al. 1995, 2001, 2006, Gamage et al. 2003, Gunatilleke et al. 1997, Singhakumara et al. 2003). For example, seedlings of Shorea worthingtonii and Mesua nagassarium are more tolerant of shade and drought than their sympatric congeners and these characteristics might explain their strong positive associations with upper-elevation spurs. These species possess relatively small leaves, low leaf surface to volume ratios, low stomatal densities per unit area and low rates of stomatal conductance (Ashton \& Berlyn 1992, Ashton et al. 2006). Compared to the other Shorea species, seedlings of $S$. worthingtonii exhibit the least plasticity in leaf anatomy between shade and sun, higher root allocation and rates of net photosynthesis, and lower mortality in deep shade (Ashton 1995). Shorea worthingtonii and M. nagassarium showed higher survival and growth in both natural and simulated upper-slope environments, and $S$. worthingtonii experienced the lowest survival and growth rates in open valley habitats in the Sinharaja landscape (Ashton et al. 1995, 2006).

Compared to the other species of Shorea, seedlings of $S$. megistophylla exhibited the greatest plasticity in growth measures and leaf morphology between shade and sun treatments and the greatest net photosynthetic rates and stomatal conductivity, largest and thickest leaves, largest stomates, thickest cuticles and greatest rates of mass gain in full-sun environments (Ashton 1995, Ashton \& Berlyn 1992). Taken together these traits provide a mechanistic explanation for the observation that seedlings of $S$. megistophylla show greatest rates of growth and survival in large canopy gaps in valleys (Ashton et al. 1995) and the positive association of stems $\geq 1 \mathrm{~cm}$ dbh to LLG (the habitat most clearly describing the valley environment at Sinharaja). Mesua ferrea, a species restricted to lower-lying areas along streams, exhibited similar growth attributes to $S$. megistophylla (Ashton et al. 2006). Differential patterns of water-use efficiency and shade tolerance among four sympatric species of Syzygium also reflect differences in their habitat preferences in the Sinharaja landscape (Gamage et al. 2003, Singhakumara et al. 2003). Similar experimental investigation of the mechanisms underlying habitat specialization in lowland dipterocarp forest at Lambir National Park, Sarawak, has emphasized the potential importance of differences in water availability between soil types (Palmiotto et al. 2004).

\section{Niche-assembly vs. dispersal-assembly mechanisms underlying species distribution}

The results from Sinharaja and other CTFS FDPs indicate that with increases in fine-scale topographic and edaphic heterogeneity, there may be a concomitant increase in the proportion of habitat specialists (Harms et al. 2001, Potts et al. 2004). At Sinharaja, habitat specialists are dispersed by gyration (dipterocarps), ballistic mechanisms (Agrostistachys) and large and small animals (most species in Appendix 1; Jayasekara et al. 2003). Consequently, this suggests that the role of dispersal agents is relatively less important than that of habitat features in spatial patterning of tree species in the Sinharaja landscape.

Phillips et al. (2003) have shown a similarly high degree of association to contrasting substrates among forest trees in Madre de Dios, south-eastern Peru and concluded that substrate-mediated local processes may play a much more important role than distance-dependent processes in structuring forest composition. Likewise, Potts et al. (2004) have shown that habitat heterogeneity and niche structure play a more important role than dispersal-based mechanisms in explaining observed species distribution patterns in a NW Borneo mixed dipterocarp forest. A larger-scale study in the Western Amazon by Fine et al. 
(2005) has shown that edaphic heterogeneity has played an important role in both allopatric and parapatric speciation of taxa within tribe Protieae of Burseraceae. However, in a FDP in terre firme forest at Yasuni in Ecuador, most species occurred in all habitats with similar densities from ridge top to valley bottom, suggesting that they might be habitat generalists (Valencia et al. 2004). Valencia et al. (2004) found little evidence for fine-grained partitioning of the topographic gradient, in contrast to the observed patterns at Sinharaja. Furthermore, Valencia et al. (2004) found that habitat specialists were mostly treelets and shrubs, whereas in Sinharaja all growth forms, including most of the abundant and canopydominant species are well represented among habitat specialists (Table 5, Appendix 1). These marked differences observed in the patterns of species distribution among forests may relate to their differences in historical and ecological biogeography, or to differences in local topography that create conditions that differentially dictate species distribution patterns (Ashton 1998, Burslem et al. 2001, Fine et al. 2005, Gamage et al. 2003, Phillips et al. 2003, Potts et al. 2004).

Finally, the neutral theory of community organization postulates that populations take random walks in abundance as they disperse, colonize, advance and retreat across landscapes (Hubbell 2001). The theory was conceived and has been explored on homogeneous landscapes (Hubbell 2001), even though real-world landscapes are heterogeneous (e.g. Figure 1). The extent that species distribution patterns are biased with respect to landscape features is the extent to which predictions made by neutral theory are not met. The present study demonstrates dramatic levels of habitat association that are inconsistent with a strict interpretation of neutrality as applied to tropical forest tree communities.

\section{ACKNOWLEDGEMENTS}

The authors gratefully acknowledge the permission given to work in Sinharaja World Heritage Site and the accommodation facilities provided by the Forest Department of Sri Lanka, as well as the generous financial assistance given to set up the plot and computerise the database by The John D. and Catherine T. MacArthur Foundation, the Smithsonian Tropical Research Institute, the U.S. National Science Foundation (grant \#0090311), Arnold Arboretum of Harvard University, and the National Institute for Environmental Studies of Japan. The Sri Lankan authors are specially thankful to Dr Richard Condit for his invaluable time spent teaching them how to analyse these large databases rapidly and to Dr Elizabeth Losos for organizing the workshops held in Bangalore in 2001, in Panama in 2002, and in Harvard Forest in 2003 where we had fruitful exchange of ideas during the preparation of this paper. KEH acknowledges support from the National Science Foundation(DEB 0211004 and OISE 0314581).

\section{LITERATURE CITED}

ANON, 2003. Inside CTFS. Newsletter of the Center for Tropical Forest Science, Summer 2003, 15 pp.

ASHTON, M. S., GUNATILLEKE, C. V. S., SINGHAKUMARA, B. M. P. \& GUNATILLEKE, I. A. U. N. 2001. Restoration pathways for rain forest in southwest Sri Lanka: a review of concepts and models. Forest Ecology and Management 154:409-430.

ASHTON, M. S., SINGHAKUMARA, B. M. P. \& GAMAGE, H. G. 2006. Interaction between light and drought affects performance of tropical tree species that have differing topographic affinities. Forest Ecology and Management 221:42-51.

ASHTON, P. M. S. 1995. Seedling growth of co-occurring Shorea species in the simulated light environments of a rain forest. Forest Ecology and Management 72:1-12.

ASHTON, P. M. S. \& BERLYN, G. P. 1992. Leaf adaptations of some Shorea species to sun and shade. New Phytologist 121:587-596.

ASHTON, P. M. S., GUNATILLEKE, C. V. S. \& GUNATILLEKE, I. A. U. N. 1995. Seedling survival and growth of four Shorea species in a Sri Lankan rain forest. Journal of Tropical Ecology 11:263-279.

ASHTON, P. S. 1964. Ecological studies in mixed dipterocarp forests in Brunei state. Oxford Forestry Memoirs, No. 25. Clarendon Press, Oxford. 75 pp.

ASHTON, P. S. 1998. Niche specificity among tropical trees: a question of scales. Pp. 491-514 in Newbery, D. M., Brown, N. D. \& Prins, H. T. T. (eds.). Dynamics of tropical communities. Blackwell Scientific, Oxford.

ASHTON, P. S. \& CTFS WORKING GROUP 2004. Floristics and vegetation of the forest dynamics plots. community ecology in an everwet forest in Sri Lanka. Pp. 119-144 in Losos, E. C. \&. Leigh, E. G. (eds.). Tropical forest diversity and dynamism: findings from a largescale plot network. The University of Chicago Press, Chicago.

BAILliE, I. C., ASHTON, P. S., COURT, M. N., ANDERSON, J. A. R., FITZEPATRICK, E. A. \& TINSLEY, J. 1987. Site characteristics and the distribution of tree species in mixed dipterocarp forests on tertiary sediments in Central Sarawak, Malaysia. Journal of Tropical Ecology 3:201-220.

BURSLEM, D.F. R. P., GUNATILLEKE, C. V.S.\& PEARSON, T. R. H. 2001. Edaphic specialization of Shorea section Doona across a topographic catena in Sri Lanka: responses to nutrient availability. Pp. 577-580 in Ganeshaiah, K. N., Shaanker, U. \& Bawa, K. S. (eds.). Proceedings of the International Conference on Tropical Ecosystems: Structure, Diversity and Human Welfare. IBH Publishing Co. Pvt. Ltd., New Delhi, India.

CONDIT, R. 1995. Research in large, long-term tropical forest plots. Trends in Ecology and Evolution 10:18-22.

CONDIT, R., HUBBELL, S. P., LAFRANKIE, J. V., SUKUMAR, R., MANOKARAN, N., FOSTER, R. B. \& ASHTON, P. S. 1996. Speciesarea and species individual relationships for tropical trees: a comparison of three 50 ha plots. Journal of Ecology 84:549-562. 
CONDIT, R., ASHTON, P. S., BAKER, P., BUNYAVEJCHEWIN, S., GUNATILLEKE, S., GUNATILLEKE, N., HUBBELL, S. P., FOSTER, R. B., ITOH, A., LAFRANKIE, J. V., LEE, H. S., LOSOS, E., MANOKARAN, N., SUKUMAR, R. \& YAMAKURA, T. 2000. Spatial patterns in the distribution of tropical tree species. Science 288:414417.

CONNELL, J. H. 1978. Diversity in tropical rainforests and coral reefs. Science 199:1302-1310.

COORAY, P. G. 1984. Geology, with special reference to the Precambrian. Pp 1-34 in Fernando, C. H. (ed.). Ecology and biogeography of Sri Lanka. Monographiae Biologicae 57. Dr. W. Junk Publishers, The Hague.

DALLING, J. W., MULLER-LANDAU, H. C., WRIGHT, S. J. \& HUBBELL, S. P. 2002. Role of dispersal in the recruitment limitation of neotropical pioneer species. Journal of Ecology 90:714-727.

DASSANAYAKE, M. D. \& FOSBERG, F. R. 1980-2000. A revised handbook to the flora of Ceylon. Vols. 1-12, Amarind Publishing, New Delhi.

DAVIES, S. J., TAN, S., LAFRANKIE, J. V. \& POTTS, M. D. 2005. Soil related floristic variation in a hyperdiverse dipterocarp forest. Pp. 2234 in Roubik, D. W., Sakai, S. \& Hamid Karim, A. A. (eds.). Pollination ecology and the rain forest, Sarawak Studies. Ecological Studies, Vol. 174. Springer Verlag, New York.

DEBSKI, I., BURSLEM, D. F. R. P., PALMIOTTO, P. A., LAFRANKIE, J. V., LEE, H. S. \& MANOKARAN, N. 2002. Habitat preferences of Aporosa in two Malaysian rain forests: implications for abundance and co-existence. Ecology 83:2005-2018.

DE ROSAYRO, R. A. 1942. The soils and ecology of the wet evergreen forests of Ceylon. The Tropical Agriculturist 98:70-80, 153175.

ERB, D. K. 1984. Land form and drainage. Pp. 35-64 in Fernando, C. H. (ed.). Ecology and biogeography of Sri Lanka. Monographiae Biologicae 57. Dr. W. Junk Publishers, The Hague.

FINE, P. V. A., DALY, D. C., MUNOZ, G. V., MESONS, I. \& CAMERON, K. M. 2005. The contribution of edaphic heterogeneity of the evolution and diversity of Burseraceae trees in the Western Amazon. Evolution 59:1464-1478.

GAMAGE, H. K., ASHTON, M. S. \& SINGHAKUMARA, B. M. P. 2003. Leaf structure of Syzygium spp. (Myrtaceae) in relation to site affinity within a tropical rain forest. Botanical Journal of the Linnean Society 141:365-377.

GARTLAN, J. S., NEWBERY, D. M., THOMAS, D. W. \& WATERMAN, P. G. 1986. The influence of topography and soil phosphorus on the vegetation of Korup Forest reserve, Cameroon. Vegetatio 65:131148.

GIMARET-CARPENTIER, C., CHESSEL, D. \& PASCAL, J.-P. 1998. Non-symmetric correspondence analysis: an alternative for species occurrences data. Plant Ecology 138:97-112.

GIMARET-CARPENTIER, C., DRAY, S. \& PASCAL, J.-P. 2003. Broadscale biodiversity pattern of the endemic tree flora of the Western Ghats (India) using canonical correlation analysis of herbarium records. Ecography 26:429-444.

GUNATILLEKE, C. V. S., GUNATILLEKE, I. A. U. N., PERERA, G. A. D., BURSLEM, D. F. R. P., ASHTON, P. M. S. \& ASHTON, P. S. 1997. Responses to nutrient addition among seedlings of eight closely related species of Shorea in Sri Lanka. Journal of Ecology 85:301311.

GUNATILLEKE, C. V. S., GUNATILLEKE, I. A. U. N., ETHUGAlA, A. U. K., WEERASEKARA, N. S., ASHTON, P. S., ASHTON, P. M. S. \& WIJESUNDARA, D. S. A. 2004. Community ecology in an everwet forest in Sri Lanka. Pp. 119-144 in Losos, E. C. \& Leigh, E. G. (eds.). Tropical forest diversity and dynamism: findings from a large-scale plot network. The University of Chicago Press, Chicago.

HARMS, K. E., CONDIT, R., HUBBELL, S. P. \& FOSTER, R. B. 2001. Habitat associations of trees and shrubs in a 50-ha neotropical forest plot. Journal of Ecology 89:947-959.

HARMS, K. E., POWERS, J. S. \& MONTGOMERY, R. A. 2004. Variation in small sapling density, understory cover and resource availability in four Neotropical forests. Biotropica 36:40-51.

HUBBELL, S. P. 2001. The unified neutral theory of biodiversity and biogeography. Princeton University Press, Princeton. 375 pp.

HUBBELL, S. P. \& FOSTER, R. B. 1983. Diversity of canopy trees in a neotropical forest and implications for conservation. Pp. 2541 in Sutton, S. J., Whitmore, T. C. \& Chadwick, A. C. (eds.). Tropical rain forest: ecology and management. Blackwell Scientific, Oxford.

HUBBELL, S. P., FOSTER, R. B., O'BRIEN, S. T., HARMS, K. E., CONDIT, R., WECHSLER, B., WRIGHT, S. J. \& LOO DE LAO, S. 1999. Light gap disturbances, recruitment limitation, and tree diversity in a neotropical forest. Science 283:554-557.

ITOH, A., YAMAKURA, T., OHKUBO, T., KANZAKI, M., PALMIOTTO, P. A., LAFRANKE, J. V., ASHTON, P. S. \& LEE, H. S. 2003. Importance of topography and soil texture in the spatial distribution of two sympatric dipterocarp trees in a Bornean rain forest. Ecological Research 18:307-320.

JAYASEKARA, P., TAKATSUKI, S., WEERASINGHE, U. R. \& WIJESUNDARA, S. 2003. Arboreal fruit visitors in a tropical forest in Sri Lanka. Mammal Study 28:161-165.

LOSOS, E. C. \& LEIGH, E. G. 2004 Tropical forest diversity and dynamism: findings from a large-scale plot network. The University of Chicago Press, Chicago. 645 pp.

MANOKARAN, N., LAFRANKIE, J. V., KOCHUMMEN, K. M., QUAH, E. S., KLAHN, J. E., ASHTON, P. S. \& HUBBELL, S. P. 1992. Stand table and distribution of species in the 50 ha research plot at Pasoh Forest Reserve. Forest Research Institute of Malaysia, Kepong, Malaysia. $454 \mathrm{pp}$.

NILUS, R. 2003. Effect of edaphic variation on forest structure, dynamics, diversity and regeneration in a lowland tropical rain forest in Borneo. Ph.D. thesis, Aberdeen University, UK.

PALMIOTTO, P.A., DAVIES, S. J., VOGT, K. A., ASHTON, M. S., VOGT, D. J. \& ASHTON, P. S. 2004. Soil related habitat specialization in dipterocarp rain forest tree species in Borneo. Journal of Ecology 92:609-623.

PHILLIPS, O. L., VARGAS, P. N., MONTEAGUDO, A. L., CRUZ, A. P., ZANS, M. C., SANCHEZ, W. G., YLI-HALLA, M. \& ROSE, S. 2003. Habitat association among Amazonian tree species: a landscape scale approach. Journal of Ecology 91:757-775.

POTTS, M. D., ASHTON, P. S., KAUFMAN, L. S. \& PLOTKIN, J. B. 2002. Habitat patterns in tropical rainforests: a comparison of 105 plots in northwest Borneo. Ecology 83:2782-2797. 
POTTS, M. D., DAVIES, S. J., BOSSERT, W. H., TAN, S. \& NUR SUPARDI, M. N. 2004. Habitat heterogeneity and niche structure of trees in two tropical rain forests. Oecologia 139:446-453.

RENNOLLS, K. \& LAUMONIER, Y. 2000. Species diversity structure analysis at two sites in the tropical rain forest of Sumatra. Journal of Tropical Ecology 16:253-270.

SINGHAKUMARA, B. M. P., GAMAGE, H. K. \& ASHTON, M. S. 2003. Comparative growth of four Syzygium species within simulated shade environments of a Sri Lankan rain forest. Forest Ecology and Management 174:511-520.

SUKUMAR, R., DATTARAJA, H. S., SURESH, H. S., RADHAKRISHNAN, J., VASUDEVA, J., NIRMALA, S. \& JOSHI, N. V. 1992. Long-term monitoring of vegetation in a tropical deciduous forest in Mudumalai, southern India. Current Science 62:608-616.

VALENCIA, R., FOSTER, R. B., VILLA, G., CONDIT, R., SVENNING, J.-C., HERNANDEZ, C., ROMOLEROUX, K., LOSOS, E., MAGARD, E. \&
BALSLEV, H. 2004. Tree species distributions and local habitat variation in the Amazon: large forest plot in eastern Ecuador. Journal of Ecology 92:214-229.

WEBB, C. O. \& PEART, D. R. 2001. High seed dispersal rates in faunally intact tropical rain forest: theoretical and conservation implications. Ecology Letters 4:491-499.

WHITFIELD, J. 2002. Ecology: neutrality versus the niche. Nature 417:480-481.

WHITMORE, T. C. 1984. Tropical rain forests of the Far East. Clarendon Press, Oxford. 352 pp.

WRIGHT, S. J. 2002. Plant diversity in tropical forests: a review of mechanisms of species co-existence. Oecologia 130:1-14.

YAMAKURA, T., KANZAKI, M., ITOH, A., OHKUBO, T., OGINO, K., CHAI, E. O. K., LEE, H. S. \& ASHTON, P. S. 1995. Topography of a large-scale research plot established within the Lambir rain forest in Sarawak. Tropics 5:41-56. 
Appendix 1. Abundant and less-abundant species, each having $\geq 800$ or $100-800$ individuals, respectively, in the Sinharaja FDP, showing significant positive $(+)$ and negative $(-)$ associations to different habitats. Abbreviations of habitat categories are explained in Table $1 . \mathrm{C}=\mathrm{Canopy}$ tree species; $\mathrm{SC}=$ Sub-canopy tree species; UT $=$ Understorey tree species; $\mathrm{ST}=$ Shrub and treelet species.

\begin{tabular}{|c|c|c|c|c|c|c|c|c|}
\hline Habitat categories & USS & ULS & USG & ULG & LSS & LLS & LSG & LLG \\
\hline \multicolumn{9}{|c|}{ Abundant species showing significant associations } \\
\hline \multicolumn{9}{|c|}{ (+) associations with upper-elevation habitats and with/without $(-)$ associations with lower-elevation habitats } \\
\hline Agrostistachys intramarginalis (ST) & + & & & & & & - & - \\
\hline Mesua nagassarium (C) & + & & & & & & & - \\
\hline Shorea worthingtonii (C) & + & & & & & & & - \\
\hline Memecylon arnottianum (ST) & & + & & & & & - & - \\
\hline Humboldtia laurifolia (UT) & & + & & & & & - & - \\
\hline Hydnocarpus octandra (SC) & & & + & & & & & \\
\hline Shorea cordifolia (SC) & & & + & & & & & - \\
\hline Palaquium petiolare $(\mathrm{C})$ & & & + & + & & & & - \\
\hline Mesua ferrea $(\mathrm{C})$ & & & + & + & & & & \\
\hline Nargedia macrocarpa (UT) & & & & + & & & & \\
\hline
\end{tabular}

(+) associations with lower-elevation habitats and with/without (-) associations with upper-elevation habitats Garcinia hermonii (UT)

Xylopia championii (UT)

Memecylon rostratum (ST)

Shorea trapezifolia $(\mathrm{C})$

Gaertnera rosea (ST)

Agrostistachys hookeri (ST)

Semecarpus walkeri (SC)

Schumacheria castaneifolia (ST)

Palaquium canaliculatum (SC)

Urophyllum ellipticum (ST)

Psychotria dubia (ST)

Bhesa ceylanica $(\mathrm{C})$

Semecarpus gardneri (SC)

Litsea longifolia (UT)

Leea indica (ST)

Shorea megistophylla (C)

Syzygium neesianum (SC)

Mastixia tetrandra (SC)

Cryptocarya wightiana (SC)

Psychotria nigra (ST)

Gaertnera vaginans (ST)

Glochidion acuminatum (ST)

Allophyllus zeylanicus (ST)

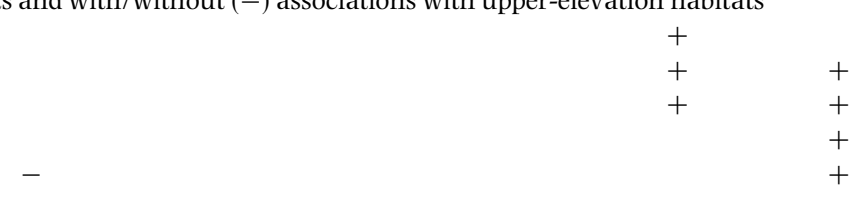

+
+
+
+

(-) associations with either upper- or lower-elevation habitats

Anisophyllea cinnamomoides (C)

Cullenia ceylanica $(\mathrm{SC})$

Palaquium thwaitesii (SC)

Shorea affinis (C)

Calophyllum thwaitesii (SC)

Shorea disticha $(\mathrm{C})$

Shorea congestiflora (C)

Cullenia rosayroana (SC)

Less-abundant species showing significant associations

$(+)$ associations with upper-elevation habitats and with/without (-) associations with lower-elevation habitats

Psychotria glandulifera (ST)

Isonandra lanceolata $(\mathrm{SC})$

Symplocos cuneata (ST)

Prismatomeris tetrandra (ST)

Lasianthus obliquus (ST)

Madhuca fulva (SC)

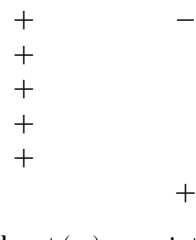

-
+
+

$\begin{array}{ll}- & \\ - & \\ - & - \\ & - \\ & -\end{array}$

$(+)$ associations with lower-elevation habitats and with/without (-) associations with upper-elevation habitats

Erythroxylum obtusifolium (ST)

Syzygium lissophyllum (SC)

Carallia calycina $(\mathrm{SC})$

Syzygium sylvestre (SC)

Dysoxylum binectariferum (C)

Aglaia apiocarpa (ST)

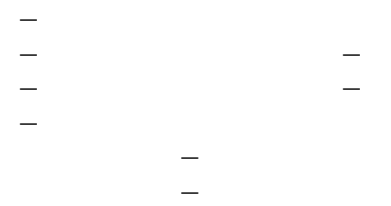

$+$ 
Appendix 1. Continued.

\begin{tabular}{|c|c|c|c|c|c|c|c|c|}
\hline Habitat categories & USS & ULS & USG & ULG & LSS & LLS & LSG & LLG \\
\hline Dysoxylum peerisi (C) & - & & & & & & + & + \\
\hline Syzygium cylindricum (SC) & - & & & & & & & + \\
\hline Syzygium wightianum (SC) & - & & & & & & & + \\
\hline Nothopodites foetida (ST) & - & - & & & & & + & + \\
\hline Psychotria pleurivenia (ST) & - & & & & & & & + \\
\hline Antidesma pyrifolium (ST) & - & & & & & & & + \\
\hline Mallotus rhamnifolius (ST & - & & & & & & & + \\
\hline Euphoria longana (SC) & - & - & & & - & & & + \\
\hline Pometia tomentosa (SC) & - & - & & & & & & + \\
\hline Scolopia acuminata (UT) & - & - & & & & & & + \\
\hline Symplocos hispidula (ST) & & - & - & & & & & + \\
\hline Actinodaphne albifrons (UT) & & - & - & - & & & & + \\
\hline Semecarpus acuminata (ST) & & - & & - & & & & + \\
\hline Diospyros insignis (UT) & & & - & & & & & + \\
\hline Calophyllum bracteatum (SC) & & & & & + & & & \\
\hline Pseudocarapa championii (C) & & & & & & + & & \\
\hline Putranjiva tomentosa (SC) & & & & & & + & & \\
\hline Garcinia spicata (UT) & & & & & & + & & \\
\hline Gomphia serrata (ST) & & & & & & + & & \\
\hline Eurya acuminata (ST) & & & & & & + & & \\
\hline Ptychopyxis thwaitesii (UT) & & & & & & & + & \\
\hline Pavetta indica (ST) & & & & & & & + & + \\
\hline Eugenia rivulorum (ST) & & & & & & & + & + \\
\hline Chaetocarpus castanocarpus (SC) & & & & & & & & + \\
\hline Axinandra zeylanica (SC) & & & & & & & & + \\
\hline Vitex altissima (SC) & & & & & & & & + \\
\hline Cinnamomum capparu-coronde (UT) & & & & & & & & + \\
\hline Cinnamoтum dubium (UT) & & & & & & & & + \\
\hline Dillenia retusa (UT) & & & & & & & & + \\
\hline Semecarpus subpeltata (UT) & & & & & & & & + \\
\hline Elaeocarpus subvillosus (UT) & & & & & & & & + \\
\hline Mallotus fuscescens (UT) & & & & & & & & + \\
\hline Thottea siliquosa (ST) & & & & & & & & + \\
\hline Glochidion zeylanicum (ST) & & & & & & & & + \\
\hline Symplocos coronata (ST) & & & & & & & & + \\
\hline Glycosmis pentaphylla $(\mathrm{ST})$ & & & & & & & & + \\
\hline \multicolumn{9}{|c|}{$(-)$ associations with either upper- or lower-elevation habitats } \\
\hline Dipterocarpus hispidus (C) & - & & & & & & & \\
\hline Urandra apicalis (SC) & & - & & & & & & \\
\hline Glenniea unijuga (SC) & & - & & & & & & \\
\hline Nothopegia beddomei (UT) & & - & & & & & & \\
\hline Campnosperma zeylanicum (C) & & & - & & & & & \\
\hline Litsea iteodaphne (ST) & & & & & & - & & - \\
\hline Syzygium makul (SC) & & & & & & & - & \\
\hline Memecylon procerum (ST) & & & & & & & - & \\
\hline Gyrinops walla $(\mathrm{UT})$ & & & & & & & - & - \\
\hline Goniothalamus hookeri (ST) & & & & & & & & - \\
\hline
\end{tabular}

